\title{
Evaluation of Growth Performance of a Genetically Characterized F1 Rainbow Trout, Oncorhynchus mykiss in a Recirculating Aquaculture System
}

\author{
José Luis Arredondo-Figueroa ${ }^{1}$, Nayeli Ismene Armendáriz-Sáenz ${ }^{2}$, \\ Laura Georgina Núñez-García ${ }^{2}$, Jesús Trinidad Ponce-Palafox ${ }^{3}$, \\ Irene De Los Angeles Barriga-Sosa²
}

\begin{abstract}
${ }^{1}$ Posta Zootécnica, Departamento de Zootecnia, Centro de Ciencias Agropecuarias, Universidad Autónoma de Aguascalientes, Jesús María, México

${ }^{2}$ Planta experimental de Producción Acuícola, Departamento de Hidrobiología, División de Ciencias Biológicas y de la Salud, Universidad Autónoma Metropolitana Iztapalapa, Iztapalapa, México

${ }^{3}$ Escuela Nacional de Ingeniería Pesquera, Unidad de Bioingeniería Costera, Universidad Autónoma de Nayarit, San Blas, México Email: arredondo60@hotmail.com, jlarredondo@correo.uaa.mx
\end{abstract}

How to cite this paper: Arredondo-Figueroa, J.L., Armendáriz-Sáenz, N.I., Núñez-García, L.G., Ponce-Palafox, J.T. and Barriga-Sosa, I. De Los A. (2017) Evaluation of Growth Performance of a Genetically Characterized F1 Rainbow Trout, Oncorhynchus mykiss in a Recirculating Aquaculture System. Agricultural Sciences, 8, 716-728.

https://doi.org/10.4236/as.2017.87053

Received: May 27, 2017

Accepted: July 26, 2017

Published: July 29, 2017

Copyright $\odot 2017$ by authors and Scientific Research Publishing Inc. This work is licensed under the Creative Commons Attribution International License (CC BY 4.0).

http://creativecommons.org/licenses/by/4.0/

(c) (i) Open Access

\begin{abstract}
The growth performance of a selected $\mathrm{F} 1$ rainbow trout genetically characterized as polymorphic with locus Omy207UoG $\left(N A=13, P I C=0.891, H_{E}=\right.$ 0.9003 ) was evaluated in a recirculating aquaculture system (RAS). A set of 157 rainbow trout of $37.8 \mathrm{~g}$ of mean body weight and $14.6 \mathrm{~cm}$ mean total length per tank, were introduced in each of six fish tank of $5 \mathrm{~m}^{3}$ connected to a recirculating aquaculture system (RAS). The trout was rearing during 317 days. Growth performance indicators and water quality were evaluated during the experiment. The genetically selected F1 rainbow trout showed a tendency towards homogeneity in growth performance along the culture period, reaching a mean total weight of $552.2 \mathrm{~g}$. The length-weight relationship indicated an isometric growth $(>3.0)$. This study presents the basis to establish a long-term marker-assisted selection program for rainbow trout culture in a subtropical region.
\end{abstract}

\section{Keywords}

Rainbow Trout, Oncorhynchus mykiss, Genetically Characterized, Growth, Performance, Water Quality

\section{Introduction}

Rainbow trout O. mykiss Walbaum, 1792 was introduced in Mexico in 1886 from South California, USA [1] [2]. Since then, the rainbow trout farming in 
Mexico had generated important economic earnings, and is one of the fifth most important species for aquaculture in Mexico nowadays [3].

Mexican trout farming had experimented serious difficulties due to problems related to a deficient genetic quality of fingerlings and the presence of bacteria and virus infectious diseases, affecting the economic income. Bacterial and viral infections in imported eggs from other countries have been reported throughout the country, particularly the Infectious Pancreatic Necrotic Virus (IPNV). This disease was confirmed in 2000 after the introduction of eggs from USA and was identified as a Buhl strain of IPNV, a West Buxton (A1) serotype of the aquatic birnavirus serogroup A [4] and confirmed in asymptomatic rainbow trout in the State of Mexico as IPNV genogroup 1 VP2 residue (221) [5].

In 2006, the Instituto Nacional de la Pesca (INAPESCA) and the Universidad Autónoma Metropolitana (UAM) Campus Iztapalapa conducted a project to set up a Reference Center of Rainbow Trout in Mexico, with the main objective to produce genetically characterized fingerlings, free of IPNV and adapted to the subtropical areas of Mexico.

Information of rainbow trout founder strains genetically characterized and adapted to subtropical conditions under intensive aquaculture systems is scarce. Available information is restricted to comparison of growth performance under experimental conditions in different types of tanks, with commercial foods, in floating-cages, with experimental diets, in small bodies of water and evaluated under different water quality [6]-[20].

The goal of the present study was to evaluate the growth performance in a recirculating aquaculture system (RAS) of a genetically characterize a selected F1 rainbow trout free of IPNV.

\section{Materials and Methods}

\subsection{Genetic Characterization of the F1 Population}

The F1 founder population $(\mathrm{n}=6,000)$ conformed by nine families was generated in September 2006 by means of perfect diallelic crosses of three genotypified o $(\mathrm{H} 089 * 296 * 526, \mathrm{H} 093 * 104 * 065, \mathrm{H} 093 * 126 * 322)$ and three $\delta(\mathrm{M} 078 * 049 * 639$, M092*876*117, M093*363*327), rainbow trout brooders were certified as free of IPNV. The brooder stock $(\mathrm{n}=150)$ was genetically and reproductively characterized elsewhere. A random sample of the F1 $(\mathrm{n}=388)$ was genotyped with the most polymorphic locus resolved for the brooder stock Omy207UoG $(N A=12$, $H_{E}=0.8571$, which showed no allele dropout, nor stuttering, nor null alleles) in order to characterized and diagnosed the polymorphism of the F1.

Tissue samples from caudal fins of each one of the sampled organisms from the F1 were obtained and maintained $95 \% \mathrm{EtOH}$ for further processing. Total DNA extraction (tDNA) was conducted according to the Dneasy ${ }^{\text {tw }}$ Tissue (QUIAGEN ${ }^{\oplus}$, USA) and Wizard SV Genomic DNA Purification System (Promega) protocols. Extracted tDNA were examined in $1.0 \%$ agarose gels (1X TAE, Tris-base, glacial acetic acid and 0.5M EDTA, $\mathrm{pH} 8.0$ ) and electrophorized at 65 $\mathrm{V} / 40 \mathrm{~mA}$ for 30 - 60 minutes. Visualization of tDNA was conducted via UV (320 
nm) light and photo documented in a Multi Genius SyngeneMR apparatus, using the Gene Snap (ver 6.02.05) software.

To amplified locus Omy207UoG in F1 we used primers 5'-ACC CTA GTC ATT CAG TCA GG-3' and 5'-GAT CAC TGT GAT AGA CAT CG-3 from O'Connell (1997), with the following amplification conditions: $94^{\circ} \mathrm{C}-2$ min (one cycle), and 35 cycles at $94^{\circ} \mathrm{C}-15 \mathrm{sec}, 54^{\circ} \mathrm{C}-15 \mathrm{sec} 72^{\circ} \mathrm{C}-30 \mathrm{sec}$.

Capillar electrophoresis was carried out in the automated sequencer system ABI Prism 3100 Avant at Laboratorio Divisional de Biología Molecular de la División de Ciencias Biológicas de la Universidad Autónoma Metropolitana Unidad Iztapalapa.

The allelic sizes resolved were determined with the Data Collection V 2.0 software and in relation to the size standard LIZ-500 in GeneMapper V 3.5.

\subsection{Genetic Characterization and Diversity of the F1}

Genetic variability was assessed by determining the following parameters at the intra-specific level: 1) number of alleles observed $(N A)$ and effective number of alleles $(E f f e A)$ were determined in Geno Dive 2.0b23 [21]; 2) polymorphic information content (PIC), allele frequencies and c) allele direct count (AC) observed and expected heterozygosity $\left(H_{O}\right.$ and $H_{E}$ ) were determined in Cervus 3.0.3 [22]. To test Hardy-Weinberg equilibrium (H-W) we used Fisher exact test as implemented in GENEPOP version 4.0.10 [23] and the $F_{I S}$ estimates for each allele were computed following [24]. $P$-values for overall $F_{I S}$ estimate were calculated by the Markov chain method using the following parameter: dememorization 10,000, 1000 batches and 10,000 iterations per batch.

\subsection{Experimental Design for Growth Performance of F1}

A total of $942 \mathrm{~F} 1$ genetically selected juveniles of rainbow trout were introduced in a RAS at Planta Experimental de Producción Acuícola (PExPA), located at 2 240 meters above sea level (masl) in Mexico City (CDMX), in six $5 \mathrm{~m}^{3}$ circular fish tanks connected to recirculating aquaculture system. In each fish tank 157 juveniles were introduced with an initial average total weight (TW) of $37.8 \pm$ $12.05 \mathrm{~g}$ and an average total length (TL) of $14.6 \pm 1.53 \mathrm{~cm}$. The experiment has a duration of 317 days.

\subsection{Feeding}

The rainbow trout were fed with commercial Steelhead food (45\% of protein and $16 \%$ of lipids; Silver Cup, Toluca, Mexico) with different pellets sizes according to the average TW and TL of fishes and were partitioned in two daily rations (10:00 and 16:00 h). The initial food rate was of $2.5 \%$ of the total biomass, decreasing according to the TW to $2 \%, 1.5 \%$ and finally $1 \%$.

\subsection{Length-Weight Relationship}

The length-weight relationship was calculated by the formula $T W=\mathrm{aTL}^{\mathrm{b}}$, where: $\mathrm{TW}=$ total weight; $\mathrm{TL}=$ total length; $\mathrm{a}=$ is the intercept and $\mathrm{b}=$ the slope; the $\mathrm{b}$ 
value was determinate through the regression of the logarithm of TW versus the logarithm of TL, and the slope of the linear adjustment is an estimation of $b$ [25]. TW was measured with a digital balance (Ohaus, model Adventure with a precision of $0.01 \mathrm{~g}$ ) and TL with a graduated ichthyometer (centimeters). Every three month biometrics samples were conducted $(n=180)$.

\subsection{Growth Performance Indicators}

At the end of the experiment the following indicators were evaluated: 1) initial TW $(\mathrm{g}), 2)$ final TW $(\mathrm{g}), 3)$ gain of TW $(\mathrm{g}), 4)$ daily growth rate (g/day), 5) yield $(\mathrm{kg}), 6)$ survival rate $(\%), 7)$ relative growth rate (RGR), 8) specific growth rate (SGR), 9) feed conversion ratio (FCR) and 10) condition factor (CF) [13] [17] [18] [26].

\subsection{Water Quality}

The water temperature and dissolved oxygen concentration was measured daily, with an oxymeter YSI55, model 55-12FT; $\mathrm{pH}$ with a digital $\mathrm{pH}$ meter Lauka model 8005 , and nitrite $\left(\mathrm{N}-\mathrm{NO}_{2}^{-}\right)$, nitrate $\left(\mathrm{N}-\mathrm{NO}_{3}^{-}\right)$, and total ammonia nitrogen (TAN) $\left(\mathrm{NH}_{3}+\mathrm{NH}_{4}\right)$ were monitored weekly with a Hach Kit model DR 5000. The non-ionized ammonia $\left(\mathrm{NH}_{3}\right)$ was calculated in tables considering TAN values and were adjusted with water temperature and $\mathrm{pH}$ values [27].

\subsection{Statistical Analysis}

Data were emptied in an Excel spreadsheet (Microsoft Office 2003) and central tendency and dispersion statistic measures were calculating. The regression curves between TW vs. TL were elaborated with the same software. Data was adjusted to a potential curve and the equation model and correlation coefficient $\left(\mathrm{R}^{2}\right)$ were obtained. In order to determine the growth tendency (isometric or allometric) a t-student test was conducted [28]. The growth rate observed during the experimental period was plotted with the program box plot of SPSS Statistics (IBM, version 18, USA).

\section{Results}

\subsection{Genetic Characterization and Diversity of the F1}

The genetic diversity parameters determined for locus Omy207UoG in $388 \mathrm{~F} 1$ organisms of $O$. mykiss are summarized in Table 1. The analyzed F1 rainbow trout was resolved as highly polymorphic, with 13 alleles, an effective number of alleles of 9.914, a PIC value of 0.8905 and high observed and expected heterozygosity values ( 0.8273 and 0.9003 , for $H_{O}$ and $H_{E}$, respectively). Fisher exact test indicated an overall low but significant departure from $\mathrm{H}-\mathrm{W}$ equilibrium at locus Omy207UoG $\left(F_{I S}=0.0812, P=0.0001\right)$. The significant results were due to deficit of heterozygotes in at least three of the alleles in the F1 analyzed (Table 1). The probability values associated with the $F$ (inbreeding)-coefficients for this sample and locus revealed significant values at alleles 118, 124 and 126. These 
Table 1. Shows the resolved allele sizes, their frequencies and direct count number (AC), number of alleles per locus $(N A)$, effective number of alleles, polymorphic information content (PIC), expected and observed heterozygosity ( $H E$ and $H O$ ) detected in locus Omy-207 for $388 \mathrm{~F} 1$ rainbow specimens studied.

\begin{tabular}{|c|c|c|c|c|c|c|c|}
\hline Alleles & Allele Frequencies (AC) & $F_{I S}$ & $N A$ & EffA & PIC & $H_{O}$ & $H_{E}$ \\
\hline 106 & $0.0425(33)$ & -0.0431 & & & & & \\
\hline 112 & $0.0735(57)$ & 0.0735 & & & & & \\
\hline 114 & $0.1508(117)$ & 0.0854 & & & & & \\
\hline 116 & $0.0683(53)$ & -0.0720 & & & & & \\
\hline 118 & $0.0619(48)$ & 0.2462 & & & & & \\
\hline 122 & $0.0258(20)$ & -0.0252 & & & & & \\
\hline 124 & $0.1198(93)$ & 0.4025 & & & & & \\
\hline 126 & $0.0941(73)$ & 0.3207 & & & & & \\
\hline 130 & $0.1443(112)$ & -0.1674 & & & & & \\
\hline 132 & $0.0374(29)$ & 0.1057 & & & & & \\
\hline 134 & $0.1198(93)$ & -0.0127 & & & & & \\
\hline 136 & $0.0335(26)$ & -0.0334 & & & & & \\
\hline \multirow[t]{2}{*}{140} & $0.0284(22)$ & -0.0279 & & & & & \\
\hline & Total & $0.0812^{*}$ & 13 & 9.914 & 0.8905 & 0.8273 & 0.9003 \\
\hline
\end{tabular}

deviations are common when non-random mating and suggest that the sampling design collects cohorts with high relatedness, as it is the case of this group of kin.

\subsection{Growth Rate}

The growth rate was expressed as increase of mean total weight (TW, g) with respect to the culture time in days. Figure 1 showed the results obtained in a period of 317 days of culture.

The figure showed a substantial growth performance tendency along the experimental period, and the table size ( $300 \mathrm{~g}$ ) was obtained after 247 days of culture.

\subsection{Total Length-Total Weight Relationship}

The equations obtained in the curve fit model showed an isometric growth (Pauly t-student: $P \leq 0.05$ ) with a slope of 3.045 and a higher adjusted with $96 \%$ with a significance of $P<0.5$ (Figure 2). Higher dispersion of data was registered.

\subsection{Growth Performance}

The results of growth performance indicators are showed in Table 2, indicating an isometric growth during the experimental period. 


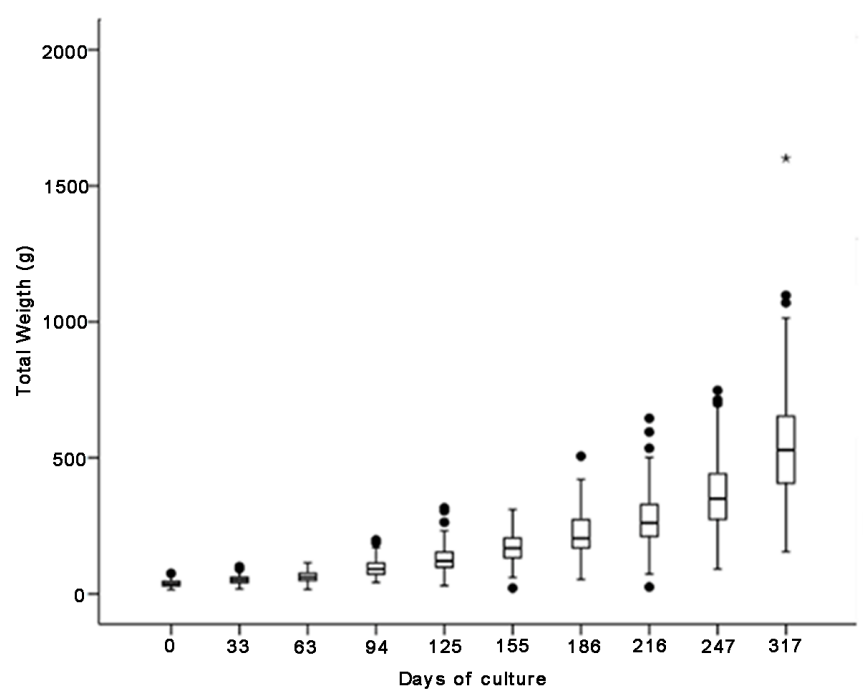

Figure 1. Boxplot graph of growth performance of the total weight (g) during the experimental period in the RAS. Initial fish average TL was $14.6 \pm 1.53 \mathrm{~cm}$ and average TW, $37.8 \pm 12.05 \mathrm{~g}$.

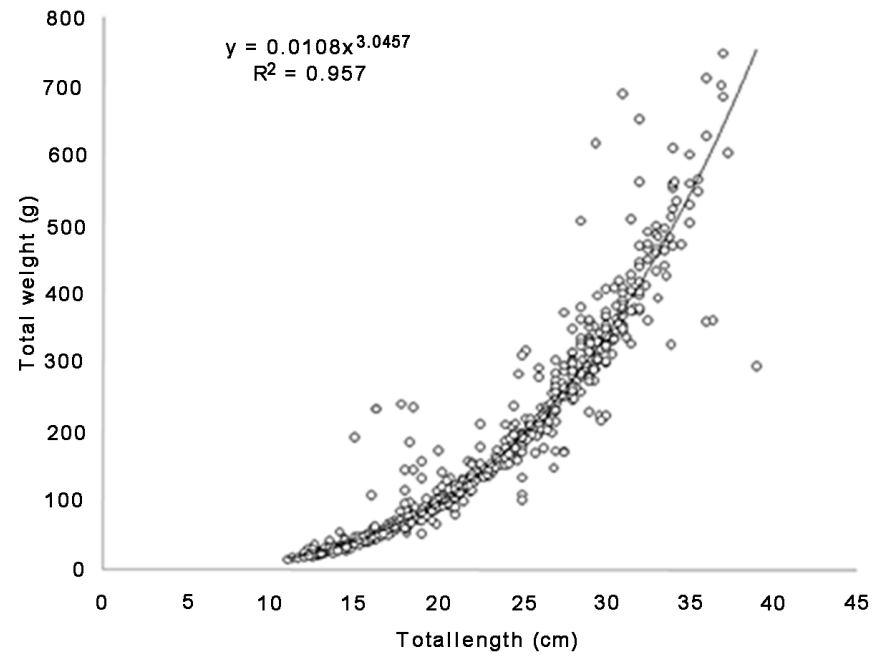

Figure 2. Lineal regression in the RAS. The curve fit model showed an isometric growth during the experimental period for fish with average initial TL $14.6 \pm 1.53 \mathrm{~cm}$ and TW, $37.8 \pm 12.05 \mathrm{~g}$.

\subsection{Water Quality}

The results of physico-chemical analysis of the systems are showed in Table 3.

\section{Discussion}

\subsection{Genetic Characterization and Diversity of the F1}

This is the first study that reports on the genetic diversity of F1 strains of rainbow trout free of infectious hematopoietic necrosis virus (IHNV) and generated by perfect diallelic crosses of genotyped sires and dams with potential use for controlled aquaculture purposes in subtropical regions. Locus Omy207UoG exhibited extraordinary high levels of genetic heterogeneity in the studied stock. 
Table 2. Average \pm standard deviation results of growth performance indicators of $\mathrm{F} 1$ rainbow trout cultured in RAS $(\mathrm{n}=6)$ during 317 days and maintained in RAS at $19.8^{\circ} \mathrm{C}$ $\pm 1.4^{\circ} \mathrm{C}$ and $\mathrm{pH} 8.1 \pm 0.4$.

\begin{tabular}{cc}
\hline Indicators & Average of each tank \\
\hline Water volume $\left(\mathrm{m}^{3}\right)$ & 26 \\
Density $\left(\mathrm{org} . / \mathrm{m}^{3}\right)$ & $37.8 \pm 10.0$ \\
Initial total weight $(\mathrm{g})$ & $552.2 \pm 112.0$ \\
Final total weight $(\mathrm{g})$ & $514.0 \pm 103.0$ \\
Gain of total weight in g & 1.6 \\
Daily growth rate $(\mathrm{g} / \mathrm{day})$ & $14.6 \pm 1.0$ \\
Initial total length $(\mathrm{cm})$ & $33.8 \pm 2.0$ \\
Final total length $(\mathrm{cm})$ & $19.2 \pm 1.0$ \\
Gain of total length $(\mathrm{cm})$ & $0.1 \pm 0.0$ \\
Daily growth rate in cm & $260.6 \pm 58.0$ \\
Total yield $(\mathrm{kg})$ & $6.0 \pm 12.0$ \\
Yield (kg/m $\left.{ }^{3}\right)$ & 78 \\
Survival rate $(\%)$ & $1392.0 \pm 176.0$ \\
Relative growth rate $(\%)$ & $0.9 \pm 0.0$ \\
Specific growth rate $\left(\% \mathrm{day}{ }^{-1}\right)$ & 1.2 \\
Feed conversion factor & 1.4 \\
Condition factor & \\
\hline
\end{tabular}

Table 3. Results of physicochemical parameters registered in the RAS during the experimental period.

\begin{tabular}{cc}
\hline Parameters & Fish tanks \\
\hline Temperature $\left({ }^{\circ} \mathrm{C}\right)$ & $19.8 \pm 1.4$ \\
Dissolved oxygen $(\mathrm{mg} / \mathrm{L})$ & $6.5 \pm 0.59$ \\
$\mathrm{pH}$ & $8.1 \pm 0.4$ \\
$\mathrm{~N}-\mathrm{NO}_{3}^{-}(\mathrm{mg} / \mathrm{L})$ & $17.8 \pm 11.56$ \\
$\mathrm{~N}-\mathrm{NO}_{2}^{-}(\mathrm{mg} / \mathrm{L})$ & $0.247 \pm 0.127$ \\
$\mathrm{TAN}^{(\mathrm{mg} / \mathrm{L})}$ & $0.535 \pm 0.269$ \\
$\mathrm{~N}-\mathrm{NH}_{3}(\mathrm{mg} / \mathrm{L})$ & $0.021 \pm 0.010$ \\
\hline
\end{tabular}

Slightly lower levels were reported for this locus in rainbow trout stocks derived from introductions to Western Australia $\left(H_{E}=0.65\right)$ [29]. However, they are high in comparison to what has been reported for rainbow trout for aquaculture purposes, using more microsatellite loci and different experimental designs in other countries. For instance, the used of nine microsatellites to characterize the genetic diversity of five strains of rainbow trout Oncorhynchus mykiss in USA 
reported levels of gene diversity (equivalent to $H_{E}$ ) that range from 0.65 to 0.83 [30], moreover, the genetic variability and differentiation of 13-farmed strains of rainbow trout from northern and Eastern Europe were determined using $10 \mathrm{mi}$ crosatellite loci and the reported $H_{E}$ values ranged from 0.42 to 0.76 [31]. A study of genotyped farmed rainbow trout was made in Norway to identify the farm of origin for escaped organism captured in a Fjord, using 12 loci and found levels of variation that range from 0.65 to $0.79\left(H_{O}\right)$ [32]. The high levels of diversity found in the F1 strain are related to the large sample sized analyzed. These genetic data present the basis to establish a long-term marker-assisted selection program for introduced rainbow trout in a subtropical region.

\subsection{Growth Performance}

In general, the F1 rainbow trout growth tendency in TW was similar to others registered in aquaculture intensive systems. Differences between densities and pond types (concrete and earth ponds) have been reported [7]. Likewise, it was demonstrated that in low densities, growth rate was higher, especially when bigger rainbow trout $(98.2 \pm 18.9 \mathrm{~g}$ and $22.5 \pm 0.94 \mathrm{~cm})$ were introduced in RAS in the PExPA, and under those conditions daily growth rate reached $3.6 \mathrm{~g}$ [6]. Similar growth rates were obtained with an initial total weight of $85.2 \mathrm{~g}$, obtaining organisms with an average of $250 \mathrm{~g}$ in four months of culture [33]. Rainbow trout exhibits different growth rates according to fish density, type of culture system, water quality and food [8]-[13] [16]. The growth rates exhibited in this study in RAS was a response of the density. Although, water quality was maintained in optimal conditions and the commercial food and the rations covered the nutritional requirements of fishes.

\subsection{Length-Weight Relationship}

It has been found that in an intensive culture TW fluctuates as a potency of length. This expression can be applied better when a fish is measured and weighted in successive phases of their life history [25], this relationship is essential for numerous studies; for example, for the estimation of growth rate, the age structure in populations and other aspects related with population dynamics. The length-weight relationship is also used to calculate the condition factor (CF), and is useful in life history comparisons of certain species [34] [35]. In aquaculture work this relationship has practical approaches because it is possible to estimate weight from length data and vice versa and to calculate other parameters such as growth tendency in time, the biomass contained in ponds, fed rations and the condition factor. When a curve model is fitted, it is possible to estimate the slope value (b) and this value was of $>3$ indicating an isometric or allometric growth [25]. The results obtained in the experiment showed values from 3.04 indicating an isometric growth (t-student, $P<0.05$ ), lineal correlation of data indicated values from $96 \%$ being highly significant and indicating an excellent fit model in spite of the dominance effect of some organisms of rainbow trout that growth faster, fed more and were dominant over other fishes. 


\subsection{Growth and Performance}

A great number of scientific papers refer to rainbow trout growth performance data with comparative purposes. In this study were used such indicators. Some authors had expressed that it is only possible to compare some indicators due the differences propitiated between different experimental conditions such as rainbow trout sizes, densities, aquaculture system, food rate, water quality, time of culture and nutritional content of foods. However, for practical purposes the growth performance indicators used in this study were important for future comparisons reasons of the selected F1 rainbow trout.

The main performance indicators for comparison purposes are feed conversion ratio (FCR), condition factor (CF) and specific growth rate (SGR). An experiment focused for the evaluation growth and survival rate of rainbow trout under different types of tanks and densities showed an average of SGR from 1.52 to 1.81, and a FCR from 1.44 to 2.51 [7]. Likewise, with the use of two types of commercial food was reported a SGR between 1.37 and 2.18, FCR from 1.04 to 1.37 and survival rate up 95\% [8]. In net cages culture was reported a SGR from 1.02 to 1.11 , a FCR from 1.37 to 1.70 and a CF of 1.39 to 1.44 [9]. With the use of experimental vegetal protein diets a SGR 1.87 to 1.94 , a FCR 1.06 to 1.12 was reported [10]. Evaluating experimental diets with different vitamin E quantities, registered a SGR from 1.87 to 1.94 and a FCR of 1.06 to 1.12 [11]. Others authors reported a SGR from 1.4 to 1.5 and a CF of 1.6. and a SGR from 0.30 to 1.21 and FC from 1.18 to 1.52 [13] [15].Testing the effects of natural pigments in rainbow trout, were reported a SGR from 1.3 to 1.6 and a FCR with an average of 1.5 [14], and in floating cage culture were recorder a SGR of 0.07 and 3.3 and a FCR from 1.1 to 1.3 [17], Yoshitomi [18] showed values of SGR from 3.0 to 3.1, with a survival rate around $99 \%$. Finally, in 21 small water bodies with a rainbow trout cage farming system, SGR fluctuated from 1.1 to 2.5 reaching a daily growth rate from 1.4 to $9.0 \mathrm{~g} /$ day. The survival rate varied from $50 \%$ to $95 \%$ [19].

The data obtained in this research confirmed that values of SGR are within the limits reported in different investigations. In RAS daily growth rate reached 1.84 g/day. The FCR presented higher values but was similar to other experiments. Then FCR and the survival rate are considered acceptable. These indicators showed similar performance when compared to other world regions, confirming that $\mathrm{F} 1$ rainbow trout maintained along the experimental period exhibited a growth rate, FCR, SGR, CF and survival rate similar to those reported in different experimental conditions.

The yield of RAS was higher. This situation is common in fish culture activities because the fish table size depends on the carrying capacity and a lesser load means a higher weight had been suggested higher load manage to obtain economical profits, however a higher fish biomass requires an expense investment for waste elimination, to maintain toxic metabolites under control and good levels of dissolved oxygen and water quality [36].

Several advantages in this RAS are relevant allowed a better control of the system, less manpower and easy harvest. On the other hand, F1 rainbow trout had 
excellent adaptation to this system such as has been showed for growth rate and performance.

\subsection{Water Quality}

The physico-chemical parameters registered in this study were found between the standard limits reported by [37]. However, the ponds water temperature was over $3^{\circ} \mathrm{C}$ of the optimum value; the dissolved oxygen (DO) was controlled by different mechanisms implemented in the RAS. There is a quite amount of information on water quality of this PExPA system [6] [14] [33] [38] and it has been probed in several occasions that water quality keeps acceptable levels allowing a good growth performance of rainbow trout. In general, DO was maintained through three main processes: 1) atmosphere interchange, 2) blower air injection and 3) injection by mean of Ventury tubes. Those mechanisms maintained high DO levels all the time, with saturation and oversaturation values that were enough to maintain appropriate conditions for rainbow trout culture, in the spite of high temperatures reached (up $19^{\circ} \mathrm{C}$ ) and high altitude (2240 masl).

The behavior of the physico-chemical parameters was similar to other recirculating aquaculture systems, for example, the water temperature and DO. The nitrite and nitrate values can be considered higher due the nitrification processes are more acute. It was also noted a difference in TAN and toxic ammonia, with an increase tendency with respect the intensification of gain of total weight. However, these chemical species never reached sub-lethal or lethal levels as those reported for rainbow trout [27].

\section{Acknowledgements}

The present study was funded by SAGARPA-CONACYT-2006-01-12147 to IDLABS and CBS-UAMI-2007-2010-147.07.03 to IDLABS and JLAF. The authors thank to Ismael Ojeda and Claudia Gárnica for laboratory and field assistance.

\section{References}

[1] Álvarez, J., Ávila, P., Calderón, G. and Chapa, H. (1961) Los recursos naturales de México. Estado actual de las investigaciones de hidrología y pesca. Instituto Mexicano de Recursos Naturales Renovables, 3, 421.

[2] Arredondo-Figueroa, J.L. and Ponce-Palafox, J.T. (2011) Bases biológicas para el cultivo de organismos acuáticos de México. Universidad Autónoma de Nayarit, Nayarit, 416.

[3] Anuario Estadístico de Acuacultura y Pesca (2006) Secretaría de Agrícultura, Ganadería, Desarrollo Rural, Pesca y Alimentación. SAGARPA, CONAPESCA, Mexico, 219.

[4] Ortega, S., César and Montes de Oca, R. (2002) Case Report: Viral Infectious Pancreatic Necrosis in Farmed Rainbow Trout from México. Journal of Aquatic Animal Health, 14, 305-310. https://doi.org/10.1577/1548-8667(2002)014<0305:CRVIPN>2.0.CO;2

[5] Guerrero, L., Herrera, E., Salinas, J., Torres, J., Montero, B.A. and Barrón, B. (2008) 
Detection and Genotyping of an Infectious Pancreatic Necrosis Virus from Asymptomatic Rainbow Trout (Oncorhynchus mykiss) Facilities in Mexico. Intervirology, 51, 285-292. https://doi.org/10.1159/000170903

[6] Arredondo F.J.L., Valdivia S.R., Hernández L.L. and Campos V.R. (1996) Evaluación del crecimiento, factor de conversión de alimento y calidad del agua del cultivo de la trucha arco iris (Oncorhynchus mykiss) en un sistema cerrado. Hidrobiológica, 5, 59-65.

[7] Alvarado, H. (1999) Crecimiento y sobrevivencia de la trucha arco iris cultivada en diferentes tipos de estanques y densidades. Veterinaria Trópical, 24, 121-129.

[8] Pokniak, J., Cornejo, S., Galleguillos, C., Larraín, C. and Battaglia, J. (1999) Efectos de la extrusión o peletización de la dieta de engorda sobre la respuesta productiva de la trucha arcoíris (Oncorhynchus mykiss) tamaño plato. Archivos de Medicina Veterinaria, 31, 141-150. https://doi.org/10.4067/S0301-732X1999000100017

[9] Akbulut, B., Sahin, T., Aksungur, N. and Aksungur, M. (2002) Effect of Initial Size on Growth Rate of Rainbow Trout, Oncorhynchus mykiss, Reared in Cages on the Turkish Black Sea Coast. Turkish Journal of Fisheries and Aquatic Sciences, 2, 133-136.

[10] Thiessen, I.D., Campbell, L.G. and Adelizi, D.P. (2003) Digestibility and Growth Performance of Juvenile Rainbow Trout (Oncorhynchus mykiss) Fed with Pea and Canola Products. Aquaculture Nutrition, 9, 67-75. https://doi.org/10.1046/j.1365-2095.2003.00203.x

[11] Yildiz, M. (2004) The Study of Fillet Quality and the Growth Performance of Rainbow Trout (Oncorhynchus mykiss) Fed with Diets Containing Different Amounts of Vitamin E. Turkish Journal of Fisheries and Aquatic Sciences, 4, 81-86.

[12] Blanc, M.J., Vallée, F., Maunas, P. and Fouriot, J.P. (2005) Maternal Variation in Juvenile Survival and Growth of Triploid Hybrids between Female Rainbow Trout and Male Brown Trout and Brook Char. Aquaculture Research, 36, 120-129. https://doi.org/10.1111/j.1365-2109.2004.01192.x

[13] Pokniak, J., Muñoz, S., Díaz, N., Saldes, A. and Cornejo, S. (2005) Evaluación de dos estrategias de pigmentación en salmón coho (Oncorhynchus kisutch). Archivos de Medicina Veterinaria, 37, 139-145. https://doi.org/10.4067/s0301-732x2005000200008

[14] Ingle de la Mora, G., Arredondo-Figueroa, J.L., Ponce-Palafox, J.T., Barriga-Sosa, I., de los A. and Vernon-Carter, E.J. (2006) Comparison of Red Chilli (Capsicum annuum) Oleoresin and Astaxanthin on Rainbow Trout (Oncorhynchus mykiss) Fillet Pigmentation. Aquaculture, 258, 497-495.

[15] Aksnes, A., Hope, B., Jönsson, E., Björnsson, B.T. and Albrektsen, S. (2006) SizeFractioned Fish Hydrolysate as Feed Ingredient for Rainbow Trout (Oncorhynchus mykiss) Fed High Plant Protein Diets. I: Growth, Growth Regulation and Feed Utilization. Aquaculture, 261, 305-317.

[16] Palti, Y., Silverstein, T.J., Wieman, H., Phillips, G.J., Barrows, T.F. and Parsons, E.J. (2006) Evaluation of Family Growth Response to Fishmeal and Gluten-Based Diets in Rainbow Trout (Oncorhynchus mykiss). Aquaculture, 255, 548-556.

[17] Morales, A.G. and Quirós, R. (2007) Desempeño productivo de la trucha arco iris en jaulas bajo diferentes estrategias de alimentación. Archivos Latinoamericanos de Producción Animal, 15, 119-127.

[18] Yoshitomi, B., Auki, M. and Oshima, S.-I. (2007) Effect of Total Replacement of Dietary Fish Meal by Low Fluoride Krill (Euphasia superba) Meal on Growth Performance of Rainbow Trout (Oncorhynchus mykiss) in Fresh Water. Aquaculture, 
266, 219-225.

[19] Maleri, M. (2009) Site Selection and Production Performance of Rainbow Trout (Oncorhynchus mykiss) Cage Operations in Small Farm Reservoirs: The Western Cape Experience, South Africa. Aquaculture Research, 40, 18-25. https://doi.org/10.1111/j.1365-2109.2008.02054.x

[20] Davidson, J.W, Kenney, P.B., Manor, M., Good, C.M., Weber, G.M., Aussanasuwannakul, A., Turk, P.J., Welsh, C. and Summerfelt, S.T. (2014) Growth Performance, Fillet Quality, and Reproductive Maturity of Rainbow Trout (Oncorhynchus mykiss) Cultured to 5 Kilograms within Freshwater Recirculating Systems. Journal of Aquaculture Research Development, 5, 238.

[21] Meirmans, P.G. and Van Tienderen, P.H. (2004) Genotype and Genodive: Two Programs for the Analysis of Genetic Diversity of Asexual Organisms. Molecular Ecology Notes, 4, 792-794. https://doi.org/10.1111/j.1471-8286.2004.00770.x

[22] Marshall, T.C., Slate, J., Kruuk, L.E.B. and Pemberton, J.M. (1998) Statistical Confidence for Likelihood-Based Paternity Inference in Natural Populations. Molecular Ecology, 7, 639-655. https://doi.org/10.1046/j.1365-294x.1998.00374.x

[23] Rousset, F. (2008) Genepop'007: A Complete Reimplementation of the Genepop Software for Windows and Linux. Molecular Ecology Resources, 8, 103-106. https://doi.org/10.1111/j.1471-8286.2007.01931.x

[24] Weir, B.S. and Cockerham, C.C. (1984) Estimating F-Statistics for the Analysis of Population Structure. Evolution, 38, 1358-1370. https://doi.org/10.1111/j.1558-5646.1984.tb05657.x

[25] Ricker, E.W. (1975) Computation and Interpretation of Biological Statistica of Fish Populations. Department of the Environment Fisheries and Marine Services, Bulletin 191, Ottawa, 382 p.

[26] Hashim, R., Chong, A.S.C., Fatan, N.A., Layman, N. and Ali, A. (2002) Production of Hybrid Red Tilapia Oreochromis mossambicus x O. niloticus at Varying Stocking Densities in Portable Canvas Tanks. Journal of Applied Aquaculture, 12, 1-12. https://doi.org/10.1300/J028v12n03 01

[27] Klontz, W.G. (1991) A Manual for Rainbow Trout Production on the FamilyOwned Farm. Nelson \& Sons, Inc., Utah, 113 p.

[28] Pauly, D. (1984) Fish Population Dynamics in Tropical Waters: A Manual for Use with Programmable Calculators. International Center for Living Aquatic Resources Management, Studies and Reviews 8, Manila, 325 p.

[29] Ward, R.D., Jorstad, K.E. and Maguire, G.B. (2003) Microsatellite Diversity in Rainbow Trout (Oncorhynchus mykiss) Introduced to Western Australia. Aquaculture, 219, 169-179.

[30] Overturf, K., Casten, M.T., LaPatra, S.L., Rexroad, C. III and Hardy, R.W. (2003) Comparison of Growth Performance, Immunological Response and Genetic Diversity of Five Strains of Rainbow Trout (Oncorhynchus mykiss). Aquaculture, 217, 93-106.

[31] Gross, R., Lulla, P. and Paaver, T. (2007) Genetic Variability and Differentiation of Rainbow Trout (Oncorhynchus mykiss) Strains in Northern and Eastern Europe. Aquaculture, 272, 139-146.

[32] Glover, K.A. (2008) Genetic Characterization of Farmed Rainbow Trout in Norway: Intra and Inter-Strain Variation Reveals Potential for Identification of Escapes. BMC Genetics, 9, 87. https://doi.org/10.1186/1471-2156-9-87

[33] Ingle de la Mora, G., Villareal-Delgado, E.L., Arredondo-Figueroa, J.L., Ponce-Pa- 
lafox, J.T. and Barriga-Sosa I.A. (2003) Evaluación de algunos parámetros de calidad del agua en un sistema cerrado de recirculación para la acuicultura, sometido a diferentes cargas de biomasa de peces. Hidrobiológica, 13, 247-253.

[34] Morato, T., Alfonso, P., Lourinho, P., Barreiros, J.P., Santos, R.S. and Nash, R.D.M. (2001) Length-Weight Relationships for 21 Coastal Fish Species of the Azores, North-Eastern Atlantic. Fisheries Research, 50, 297-302.

[35] Moutopoulos, D.K. and Stergiou, K.I. (2002) Length-Weight and Length-Length Relationships of Fish Species from Aegean Sea (Greece). Journal of Applied Ichthylogy, 18, 200-203. https://doi.org/10.1046/j.1439-0426.2002.00281.x

[36] Losordo, M.T., Masser, P.M. and Rakocy, J. (1998) Recirculating Aquaculture Tank Production Systems. An Overview of Critical Considerations. Southern Regional Aquaculture Center, 451, 6 p.

[37] Wedemeyer, G.A. and Wood, J.W. (1974) Stress as Predisposing Factor in Fish Disease. FDL-38, U.S. Department Interior Fish Wild Life Service, 28 p.

[38] Arredondo-Figueroa, J.L., Ingle de la Mora, G., Guerrero-Legarreta, I., Ponce-Palafox, J.T. and de los Barriga-Sosa, I.A. (2007) Ammonia and Nitrite Removal Rates in a Closed Recirculating-Water System under Three Load Rates of Rainbow Trout Oncorhynchus mykiss. Revista Mexicana de Ingeniería Química, 6, 301-308.

\section{Submit or recommend next manuscript to SCIRP and we will provide best service for you:}

Accepting pre-submission inquiries through Email, Facebook, LinkedIn, Twitter, etc. A wide selection of journals (inclusive of 9 subjects, more than 200 journals)

Providing 24-hour high-quality service

User-friendly online submission system

Fair and swift peer-review system

Efficient typesetting and proofreading procedure

Display of the result of downloads and visits, as well as the number of cited articles

Maximum dissemination of your research work

Submit your manuscript at: http://papersubmission.scirp.org/

Or contact as@scirp.org 